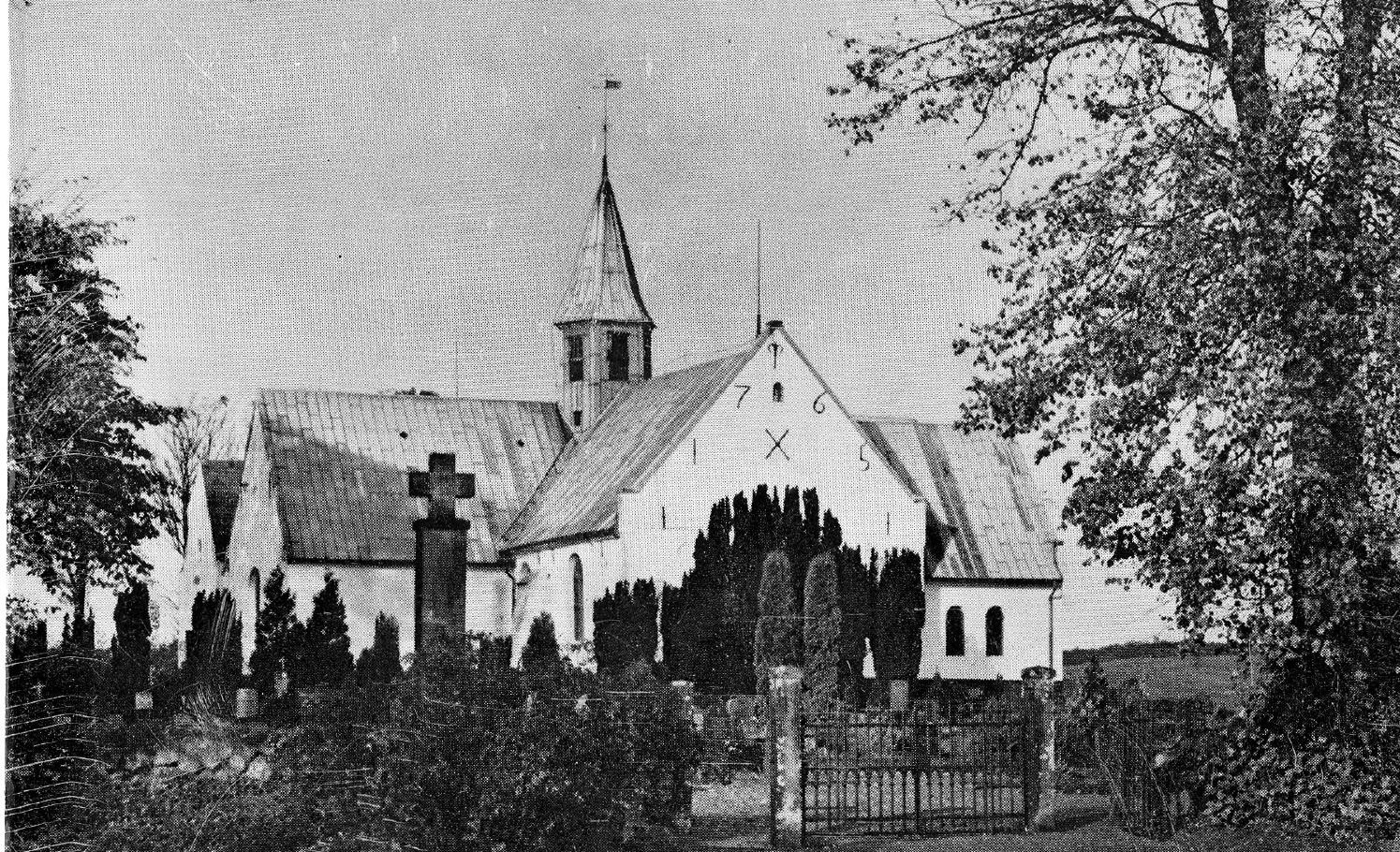

\title{
SØNDERJYSKE ARBØGER
}

UDGIVET AF

HISTORISK SAMFUND FOR SøNDERJYLLAND 


\section{HISTORISK SAMFUND FOR SØNDERJYLLAND}

henleder opmarksomheden på sine publikationer $i$ skriftrakken og $i$ den lille serie af levnedsskildringer.

Mon der ikke her er en gaveidè?

I året 1962 er folgende nyheder udsendt:

Harald Jorgensen :

To ungdomsvenner. II. P. Hanssen . II. Y. Clausen. En brevveksling.

Indb. $15,00 \mathrm{kr}$.

H. Hejselbjerg Paulsen :

Sønderjydsk Psalmesang 1717-1740.

Indb. 22,00 kr.

H. V. Gregersen:

Den Lüneburgske Saltoktroi. Et bidrag til salthandelens historie i hertugdommet Slesvig.

Indb. $17,00 \mathrm{kr}$.

Th. Kaufmann :

Minder og tanker. Erindringer rra grænselandet.

Indb. $5,50 \mathrm{kr}$.

Fortegnelse over $\phi v r i g e$ publikationer tilscondes på forlangende.

Bøgerne fảs ved henvendelse til ekspeditionen, Landsarkivet, Åbenrå.

Omslagsbilledet:

Hoptrup kirke.

Fot. 1962, Holger Cluusen, Ảbenrà. 


\section{SØNDERJYSKE A RB ØGER}

UDGIVET AF

HISTORISK SAMFUND FOR SØNDERJYLLAND

VED

J()HAN HVIDTFELDT, PETER KR. IVERSEN OG

KNUD FAN

Ig62

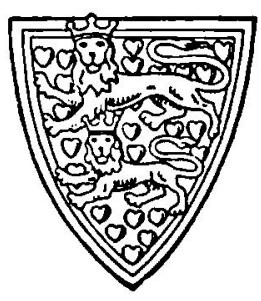



Ernst Christensch: Iandbevalnningen på Als under 'Treärskrigen $\ldots \ldots \ldots \ldots \ldots \ldots \ldots \ldots \ldots \ldots \ldots$

Henning Heilesen: De sonderjyske gråbrodreklostres underside $\quad 1-39$

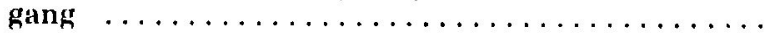

H. F. Petersen: De sunderjyske vajsenhuse .......

Jens Holdt: Hans Tonnesen. En nordslesvigsk praest 18.54-

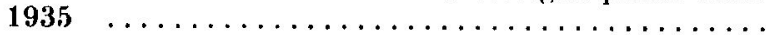

Ole Harck: Klus et middelalderligt valfartssted ......

H. I. Gregersen: Haderslevs, Ảbenris og Sunderborgs krav om dansk retssprog efter $1850 \ldots \ldots \ldots \ldots \ldots \ldots$

Sigvard Skov: Sophus Schack og slaget ved Ullerup 1849 Berge L. Burlose: Friseren Bende Bendsen 1787-1875 . . .

Inmeldelser:

D.H.F.s hândbogsserie og Bauers kalender (ved Hans Worsuel ................... Johan Hvidtfeldt og Peter Kr. Iversen: Ähenra Bys Historie I (ved Poul Kürstein) . . . . . . . . . G. Japsen: Den nationale udvikling i Ảbenrả 18001850 (ved Poul Kürsteinl ............... Troels Fink: Ustabil balance. Dansk og udenrigs forsvarspolitik 1894-1905 (ved A. Feilberg Jorgen-

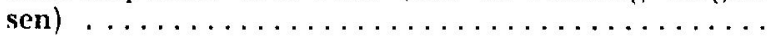

Sigurd Schoubye: Guldsmede-húndværket i Tunder og på Tonder-egnen 1550-1900 (ved Helge Sogaard) H. Hejselbjerg Paulsen: Sonderjydsk Psalmesang 1717-1740 (ved Urhan Schroder) ...........

Bognyt (ved Olav Christensen, H. V. Gregersen, Peter Kr. Iversen, Thomas Madsen, Hans Worsoe, Knud Fanı)

\section{Noter og nyt:}

Chr. Maibull $\dagger$ - Landsarkivet - Haderslev Jyhistoriske arkiv - Haderslev Amts Museum - Abenrả Museum - Museet på Sonderborg Slot - Tonder Museum - Situationen vedrorende restaureringen af Sonderborg Slot — Arkæologisk virksomhed i Sydslesvig og Holsten - To langdysser ved Sønderjyllands vestkyst - Hjemstavnsudstilling i Hovslund - Den store egnsvandring d. 9. sept. 1962 - Prisopgaver - Amtskredsenes arbejde $\ldots \ldots \ldots \ldots$

Arsberetning og regnskab 1961-62 (ved Peter Kr. Iversen og Olav Christensen) .................

Tillag til medlemsfortegnelsen ............... Manuskript og forkortelser $i$ Sanderjyske Arbøger ...... 
